\title{
Erratum to: Seabed dynamics in a large coastal embayment: 180 years of morphological change in the outer Thames estuary
}

Helene Burningham · Jon French

Published online: 4 October 2011

(C) Springer Science+Business Media B.V. 2011

Erratum to: Hydrobiologia (2011) 672:105-119 DOI 10.1007/s10750-011-0760-y

Due to an unfortunate mistake in the production process, a typographical error was introduced in the title of the original publication. The correct title is published above and should be treated as definitive by the reader.

The online version of the original article can be found under doi:10.1007/s10750-011-0760-y.

H. Burningham $(\varangle) \cdot$ J. French Coastal \& Estuarine Research Unit, Department of Geography, University College London, London, UK e-mail: h.burningham@ucl.ac.uk 